九州大学学術情報リポジトリ

Kyushu University Institutional Repository

\title{
Mineralogy of Soils from Different Agroecological Regions of Bangladesh : Region 18-Young Meghna Estuarine Floodplain
}

Akter, Fouzia

Department of Soil Science, Bangladesh Agricultural University

Moslehuddin, Abu Zofar Md.

Department of Soil Science, Bangladesh Agricultural University

Kader, Mohammed Abdul

Department of Soil Science, Bangladesh Agricultural University

Sarker, Md. Mosharaf Hossain

Department of Soil Science, Sylhet Agricultural University

他

https://doi.org/10.5109/1543409

出版情報: 九州大学大学院農学研究院紀要. 60 (2)，pp.457-462，2015-09-18. Faculty of Agriculture, Kyushu University

バージョン :

権利関係 : 


\title{
Mineralogy of Soils from Different Agroecological Regions of Bangladesh: Region 18-Young Meghna Estuarine Floodplain
}

\section{Fouzia AKTER ${ }^{1}$, Abu Zofar Md. MOSLEHUDDIN ${ }^{1}$, Mohammed Abdul KADER ${ }^{1}$, Md. Mosharaf Hossain SARKER ${ }^{2}$ and Yuki MORI*}

\author{
Laboratory of Soil Science, Division of Bioproduction Environmental Sciences, \\ Department of Agro-environmental Sciences, Faculty of Agriculture, \\ Kyushu University, Fukuoka 812-8581, Japan \\ (Received May 7, 2015 and accepted May 19, 2015)
}

\begin{abstract}
Bangladesh is consisting of 30 Agroecological Regions (AEZs) and the applied agricultural research has been conducted based on this. In context of the lack of enough information on mineralogy based on AEZs, an attempt has been taken to study the mineralogy of important soils from all AEZs of Bangladesh in order to provide basic information for applied research. As part of this attempt, the mineralogy of twenty four soils from three representative soil series (Ramgati, Hatiya and Silonia) of AEZ 18, Young Meghna Estuarine Floodplain, has been reported in the current paper. The clay content of the surface soils ranged from 8.7 to 29.4\%. According to the USDA system, thirteen soil samples were silt loam, eight were silt and only one was silty clay loam. The $<2 \mu \mathrm{m}$ clay fraction was dominated by mica. Chlorite and kaolinite were also identified as dominant mineral in almost all soils. Smectite, and vermiculite and/or vermiculite-chlorite intergrade minerals were also detected in most soils. The variation in the mineralogical composition was supposed to be attributed from the difference in the proportion of parent sediments from three major rivers of Bangladesh.
\end{abstract}

Key words: clay mineralogy, parent material, Bangladesh

\section{INTRODUCTION}

Bangladesh economy is still based on agriculture. The contribution of agricultural sector to the GDP is $19.29 \%$ and manpower involved in agriculture is $25.7 \%$ (AIS, 2013). Being a dominant factor, soil influences the crop productivity of an area. The total land area of Bangladesh is divided into 30 agro ecological regions, 88 sub regions and 535 agro ecological units (AEZs) based on physiography, soils, inundation land types and agro climate (FAO-UNDP, 1988); refer to the previous paper (Islam et al., 2003) for the map of AEZs. Now a days, agricultural research, and technology generation and transfer etc. are mostly going on the AEZ basis. For an example, fertilizer recommendation and crop suitability advises are provided here mostly based on AEZ (BARC, 2012). Soil minerals and extent of their weathering are directly relevant with nutrient release, fixation, losses and finally with nutrient management and fertilizer recommendation. Thus, mineralogical study of soil is essential to have an idea on physico-chemical properties, nutrient behavior as well as inherent potentiality of soils. In addition, minerals are the indicator of the extent of weathering that has taken place, and the presence or absence of particular minerals give clues to how soil have been formed. Considering the above, an attempt has been made to study mineralogy of important soils from all AEZs of Bangladesh. As part of this, the mineralogy of the Young Meghna Estuarine Floodplain soil, the $18^{\text {th }}$ AEZ of Bangladesh has been reported in this paper. This

\footnotetext{
Department of Soil Science, Bangladesh Agricultural University, Mymensingh 2202, Bangladesh

Department of Soil Science, Sylhet Agricultural University, Sylhet 3100, Bangladesh

* Corresponding author (E-mail: y-mori@agr.kyushu-u.ac.jp)
}

AEZ occupies an extensive area of $9269 \mathrm{~km}^{2}$ in the south-west of the country that covers Chittagong, Feni, Noakhali, Lakshmipur, Bhola, Barisal, Patuakhali and Barguna districts having young alluvial land in and adjoining the Meghna estuary. It is almost level with low ridges and broad depressions. The major soils are grey to olive, deep, silt loam and silty clay loams which are stratified either throughout or at a shallow depth. Young soils are calcareous throughout and mainly saline in dry season, while older soils are noncalcareous and are only very slightly or non saline. Calcareous Alluvium is the dominant general soil types with few Calcareous Grey Floodplain Soils and Non calcareous Grey Floodplain Soils (FAO-UNDP, 1988). Moslehuddin et al. (1999) summarized all available information on clay mineralogy of Bangladesh and proposed a tentative clay mineralogical map of Bangladesh and put soils of the AEZ 18 under mica-smectite suite based on some assumptions on the geology, as almost no data on mineralogy were available of these soils. The present study is done to verify this to get a clear idea on the mineralogy of this AEZ.

\section{MATERIALS AND METHODS}

\section{Soils used}

The AEZ 18, Young Meghna Estuarine Floodplain was selected for the present study. Twenty-four soil samples comprising three major soil series, of $0-15 \mathrm{~cm}$ depth, were collected from this AEZ. The soil series were Ramgati (13 samples), Hatiya (8 samples) and Silonia (3 samples). The samples were dried at room temperature, mixed thoroughly, crushed, sieved with a $2 \mathrm{~mm}$ sieve and preserved in plastic containers for subsequent laboratory analysis. General features of each sampling site are presented in Table 1. 
Table 1. General information of the sampled soils

\begin{tabular}{|c|c|c|c|c|}
\hline Sample name & Land type $e^{1)}$ & USDA Soil Taxonomy & Land Use & Location \\
\hline Ramgati -1 & MHL & Aeric Fluvaquents & $\begin{array}{l}\text { Rice, Wheat, } \\
\text { Maize, Mustard }\end{array}$ & $\begin{array}{l}\text { Upazila }^{2)} \text { : Sudharam } \\
\text { District: Noakhali }\end{array}$ \\
\hline Ramgati- 2 & MHL & Aeric Fluvaquents & $\begin{array}{l}\text { Rice, Wheat, } \\
\text { Maize, Mustard }\end{array}$ & (same as above) \\
\hline Ramgati-3 & MHL & Aeric Fluvaquents & $\begin{array}{l}\text { Rice, Wheat, } \\
\text { Maize, Mustard }\end{array}$ & (same as above) \\
\hline Ramgati-4 & MHL & Aeric Fluvaquents & $\begin{array}{l}\text { Rice, Wheat, } \\
\text { Maize, Mustard }\end{array}$ & (same as above) \\
\hline Ramgati-5 & MHL & Aeric Fluvaquents & Rice & $\begin{array}{l}\text { Village: Char Kakra } \\
\text { Upazila: Companigonj } \\
\text { District: Noakhali }\end{array}$ \\
\hline Ramgati-6 & LL & Aeric Fluvaquents & Rice, Pulse & $\begin{array}{l}\text { Village: Rampur } \\
\text { Upazila: Companigonj } \\
\text { District: Noakhali }\end{array}$ \\
\hline Ramgati-7 & MLL & Aeric Fluvaquents & Rice, Pulse & (same as above) \\
\hline Ramgati-8 & MHL & Aeric Fluvaquents & Rice & $\begin{array}{l}\text { Village: Ghoshbag } \\
\text { Upazila: Companigonj } \\
\text { District: Noakhali }\end{array}$ \\
\hline Ramgati-9 & LL & Aeric Fluvaquents & Rice & $\begin{array}{l}\text { Village: Sundarpur } \\
\text { Upazila: Kabirhat } \\
\text { District: Feni }\end{array}$ \\
\hline Ramgati-10 & MHL & Aeric Fluvaquents & Rice, Wheat & $\begin{array}{l}\text { Village: Char Dharbesh } \\
\text { Upazila: Sonagazi } \\
\text { District: Feni }\end{array}$ \\
\hline Ramgati-11 & MHL & Aeric Fluvaquents & Rice, Pulse, Oil seed & $\begin{array}{l}\text { Village: Char Chandia } \\
\text { Upazila: Sonagazi } \\
\text { District: Feni }\end{array}$ \\
\hline Ramgati-12 & MHL & Aeric Fluvaquents & Rice, Pulse, Oil seed & $\begin{array}{l}\text { Village: Sujapur } \\
\text { Upazila: Sonagazi } \\
\text { District: Feni }\end{array}$ \\
\hline Ramgati-13 & MLL & Aeric Fluvaquents & Rice & $\begin{array}{l}\text { Village: Sahpur } \\
\text { Upazila: Sonagazi } \\
\text { District: Feni }\end{array}$ \\
\hline Hatiya-1 & MHL & Aeric Fluvaquents & $\begin{array}{l}\text { Rice, Wheat, } \\
\text { Maize, Mustard }\end{array}$ & $\begin{array}{l}\text { Village: Noakhali Sadar } \\
\text { Upazila: Sudharam } \\
\text { District: Noakhali }\end{array}$ \\
\hline Hatiya-2 & MHL & Aeric Fluvaquents & $\begin{array}{l}\text { Rice, Wheat, } \\
\text { Maize, Mustard }\end{array}$ & (same as above) \\
\hline Hatiya-3 & MHL & Aeric Fluvaquents & $\begin{array}{l}\text { Rice, Wheat, } \\
\text { Maize, Mustard }\end{array}$ & (same as above) \\
\hline Hatiya-4 & MHL & Aeric Fluvaquents & $\begin{array}{l}\text { Rice, Wheat, } \\
\text { Maize, Mustard }\end{array}$ & (same as above) \\
\hline Hatiya-5 & MHL & Aeric Fluvaquents & Rice, Chilli & $\begin{array}{l}\text { Village: Char Elahi } \\
\text { Upazila: Companigonj } \\
\text { District: Noakhali }\end{array}$ \\
\hline Hatiya-6 & MLL & Aeric Fluvaquents & Rice & (same as above) \\
\hline Hatiya-7 & MLL & Aeric Fluvaquents & Rice, Pulse & $\begin{array}{l}\text { Village: Adrasha Gram } \\
\text { Upazila: Sonagazi } \\
\text { District: Feni }\end{array}$ \\
\hline
\end{tabular}


Table 1: (Continued)

\begin{tabular}{lllll}
\hline Sample name & Land type $^{1)}$ & USDA Soil Taxonomy & Land Use & Location \\
\hline Hatiya-8 & MLL & Aeric Fluvaquents & Rice & (same as above) \\
Silonia-1 & MLL & Aeric Fluvaquents & Rice, Pulse & Village: Char Kakra \\
& & & Upazila: Companigonj \\
& & & District: Noakhali \\
Silonia-2 & LL & Aeric Fluvaquents & Rice & Village: Musapur \\
& & & Upazila: Companigonj \\
Silonia-3 & MLL & Aeric Fluvaquents & Rice & District: Noakhali \\
& & & Village: Char Fakira \\
& & & Upazila: Companigonj \\
& & & District: Noakhali
\end{tabular}

${ }^{1)}$ MHL=Medium high land, MLL=Medium Low Land, LL=Low Land, which is normally flooded up to a depth of $90 \mathrm{~cm}, 90-180 \mathrm{~cm}, 180-270 \mathrm{~cm}$, respectively during the monsoon season.

2) Upazila=Subdistrict

\section{Particle-size analysis}

The soils were treated with $7 \% \mathrm{H}_{2} \mathrm{O}_{2}$ to decompose organic matter, stirred with a mechanical stirrer, and adjusted to $\mathrm{pH} 10$ using $1 \mathrm{M} \mathrm{NaOH}$. The $<2 \mu \mathrm{m}$ clay fraction was separated with repeated stirring-sedimentation-siphoning. The $2-20 \mu \mathrm{m}$ clay fraction was separated with repeated sedimentation-siphoning, and 20-53, 53-212, 212-2000 $\mu \mathrm{m}$ fractions were separated by wet sieving. Weight of each fraction was determined to calculate particle-size distribution.

\section{Mineralogical analysis of clay fraction}

Mineralogical composition of the clay fraction of the soils under study was determined by X-ray diffraction (XRD) method. Duplicate sols containing $50 \mathrm{mg}$ of clay $(<2 \mu \mathrm{m})$ were placed in $10 \mathrm{~mL}$ centrifugal tubes. Washing by centrifugation and decantation were carried out twice with $8 \mathrm{~mL}$ of an equal mixture of $1 \mathrm{M} \mathrm{NaCl}$ and $1 \mathrm{M}$ $\mathrm{CH}_{3} \mathrm{COONa}(\mathrm{pH} 5)$ in order to decrease the $\mathrm{pH}$ of preserved clay sols. Of the duplicate sets, one was saturated with $\mathrm{K}$ and the other with $\mathrm{Mg}$ by washing three times with $8 \mathrm{~mL}$ of $1 \mathrm{M} \mathrm{KCl}$ and $0.5 \mathrm{M} \mathrm{MgCl}_{2}$, respectively. Excess salt was removed by washing once with $8 \mathrm{~mL}$ of water. Clay in the tube was thoroughly suspended with $1 \mathrm{~mL}$ of water. An aliquot of $0.4 \mathrm{~mL}$ of the sol was dropped on to a glass slide $(7.6 \mathrm{~cm} \times 2.6 \mathrm{~cm})$, covering two-thirds of its area, air-dried and X-rayed (Parallel powder mount). The XRD patterns were obtained using a Rigaku X-ray diffractometer (RINT $2100 \mathrm{~V}$ ) with $\mathrm{Cu}$ $\mathrm{K} \alpha$ radiation at $40 \mathrm{kV}$ and $20 \mathrm{~mA}$, and at a scanning speed of $2^{\circ} 2 \theta \mathrm{min}^{-1}$ over a range of 3 to $30^{\circ}, 2 \theta$. In addition to the air-dried specimen, the Mg-saturated clay was X-rayed after solvation with glycerol, and the $\mathrm{K}$-saturated clay was X-rayed after heating at 300 and $550^{\circ} \mathrm{C}$ for $2 \mathrm{hrs}$.

\section{RESULTS}

\section{Particle-size distribution}

Particle-size distribution and textural classes as determined by the USDA system of soils under study are shown in Table 2. Each soil sample was fractioned into five groups, viz. $<2,2-20,20-53,53-212$ and 212$2000 \mu \mathrm{m}$. The clay content $(<2 \mu \mathrm{m})$ varied widely from $8.7 \%$ in Silonia-1 to $29.4 \%$ in Hatiya-2. Four soils (Ramgati-6, Hatiya-2, Hatiya-6, and Hatiya-8) had clay content of above $25 \%$ and five soils (Ramgati-7, Ramgati-10, Hatiya-3, Silonia-2 and Silonia-3) had between 20 to $25 \%$ while others had below 20\%. The $2-20 \mu \mathrm{m}$ fraction content varied from $28.4 \%$ in Hatiya -7 soil to $64.5 \%$ in Hatiya-1 soil. The $20-53 \mu \mathrm{m}$ fraction content varied from $15.5 \%$ in Hatiya-2 and $50.5 \%$ in Silonia-1 soil. The sand fraction (53-212 $\mu \mathrm{m})$ was found in a range from $0.2 \%$ in three soils (Ramgati-8, Ramgati-12 and Silonia-2) to 25.1\% in Ramgati-4 soil. The $212-2000 \mu \mathrm{m}$ sand fraction found in very negligible amount varied from $0.1-3.4 \%$. All the soils under study were medium textured, either silt or silt loam, the only exception was the Hatiya-2 soil which was silty clay loam as per USDA system.

\section{Mineralogical composition of clay fraction}

The XRD patterns of the clay $(<2 \mu \mathrm{m})$ fraction of the Ramgati-1, Ramgati-8, Hatiya-2 and Silonia-3 soils were shown in Fig. 1. The peaks of the XRD patterns were usually sharp, indicating good crystallinity and/or large crystallite size of the minerals. Mica was identified by the presence of $10 \AA$ peak reflection appearing in all the treatments. Chlorite was identified by the reflection of the $14.2 \AA$ peak in the $\mathrm{K}$-saturated and $550^{\circ} \mathrm{C}$ heated specimen while the presence of kaolinite was ascertained by the decrease in the $7.14 \AA$ peak intensity after heating of the $\mathrm{K}$-saturated specimen at $550^{\circ} \mathrm{C}$. To measure the intensities of the chlorite and kaolinite, the $7.14 \AA$ peak intensity of the $\mathrm{Mg}$-saturated and glycerol solvated specimen was allocated between chlorite and kaolinite according to the intensity ratio of the $3.54 \AA$ (chlorite) and $3.57 \AA$ (kaolinite) peaks. The presence of smectite was suggested by the broad bulge around $18 \AA$ in the Mg-saturated and glycerol solvated specimen. 
Table 2. Particle-size Distribution and textural classes of the sampled soils

\begin{tabular}{lcccccl}
\hline \multirow{2}{*}{ Soil series } & \multicolumn{5}{c}{ Particle-size Distribution (\%) } & Soil Texture \\
\cline { 2 - 5 } & $<2 \mu \mathrm{m}$ & $2-20 \mu \mathrm{m}$ & $20-53 \mu \mathrm{m}$ & $53-212 \mu \mathrm{m}$ & $212-200 \mu \mathrm{m}$ & (USDA) \\
\hline Ramgati-1 & 12.5 & 44.3 & 39.8 & 2.6 & 0.7 & Silt loam \\
Ramgati-2 & 17.1 & 52.2 & 25.9 & 4.2 & 0.6 & Silt loam \\
Ramgati-3 & 11.2 & 54.8 & 27.3 & 3.3 & 3.4 & Silt \\
Ramgati-4 & 10.0 & 33.6 & 30.3 & 25.1 & 1.0 & Silt loam \\
Ramgati-5 & 11.7 & 40.1 & 47.2 & 0.9 & 0.1 & Silt \\
Ramgati-6 & 21.6 & 58.7 & 19.1 & 0.3 & 0.1 & Silt loam \\
Ramgati-7 & 21.8 & 58.5 & 16.5 & 0.3 & 0.1 & Silt loam \\
Ramgati-8 & 10.0 & 45.6 & 42.7 & 1.6 & 0.1 & Silt \\
Ramgati-11 & 16.0 & 39.0 & 30.6 & 13.8 & 0.6 & Siltloam \\
Ramgati-12 & 17.0 & 54.5 & 26.4 & 0.2 & 0.3 & Siltloam \\
Ramgati-13 & 10.7 & 57.4 & 30.7 & 0.8 & 0.4 & Silt \\
Hatiya-1 & 13.0 & 64.5 & 20.3 & 1.6 & 0.5 & Silt \\
Hatiya-2 & 29.4 & 53.3 & 15.5 & 1.0 & 0.8 & Silty clay loam \\
Hatiya-3 & 21.6 & 56.6 & 20.4 & 1.1 & 0.2 & Silt loam \\
Hatiya-4 & 11.5 & 44.4 & 40.2 & 3.6 & 0.4 & Silt \\
Hatiya-5 & 11.6 & 50.9 & 36.7 & 1.1 & 0.1 & Silt loam \\
Hatiya-7 & 27.3 & 28.4 & 42.7 & 1.5 & 0.1 & Silt loam \\
Hatiya-8 & 25.8 & 51.1 & 22.5 & 0.4 & 0.2 & Silt loam \\
Silonia-1 & 8.7 & 40.3 & 50.5 & 0.3 & 0.1 & Silt \\
Silonia-2 & 20.8 & 54.1 & 24.9 & 0.2 & 0.1 & Silt loam \\
Silonia-3 & 24.8 & 53.3 & 21.4 & 0.5 & 0.1 & Silt loam \\
\hline
\end{tabular}

Vermiculite was identified by the decrease in the intensity of the $14.2 \AA$ peak of Mg-saturated specimen with the corresponding increase in the intensity of the $10 \AA$ peak by $\mathrm{K}$-saturation and air-drying, and the vermiculite intensity could be calculated by subtracting the intensity of the $14.2 \AA$ peak of the K-saturated and air-dried specimen from that of the $\mathrm{Mg}$-saturated and glycerol-solvated specimen. To identify and calculate the intensities of quartz, goethite and feldspars 4.25, 4.18 and $3.2 \AA$ peaks, respectively, were used.

Approximate mineral composition of the clay fraction $(<2 \mu \mathrm{m})$ was estimated based on the relative peak intensities of the respective minerals in XRD charts following Moslehuddin and Egashira (1996) and was presented in Table 3. Five layer silicates (mica, smectite, chlorite, vermiculite, kaolinite) and two complex silicate minerals (quartz, feldspar), one Fe-mineral (goethite) and two interstratified mineral (mica-chlorite, vermiculite-chlorite) were identified in variable amounts in soils under study. Mica was the most predominant mineral in all the soils ranges from $28 \%$ in Silonia-1 to $53 \%$ in Hatiya-5 and Ramgati-10 soils. Next to mica, chlorite and kaolinite were found in all soils ranges between 14-26\% and 4-20\%, respectively. The smectite was identified in twenty samples ranging from 2 to $16 \%$ while vermiculite was detected in thirteen samples in a range of 2 to $8 \%$. In addition, vermiculite-chlorite intergrade was detected in four samples (3-16\%) and interstratified mica-chlorite was found in only two samples. Other than layer silicates, quartz was found in all soils (4-16\%), goethite in five soils (1-2\%) and feldspar in all soils (1-11\%).

\section{DISCUSSION}

Particle-size distribution showed that the soils were predominantly medium textured with silt loam to silt texture. Most soils had good amounts of clay. The clay content varied with soils from low to high level, mostly on the basis of land type. In general, soils located on higher sites (medium highland) had the lower clay content than those on lower sites (medium lowland and lowland). This is mainly due to deposition of finer particles in the lower position from the surrounding elevation through run-off water. The most predominant particle was $2-20 \mu \mathrm{m}$ followed by $20-53 \mu \mathrm{m}$ fractions, both of which make the "silt" particle in USDA system. High silt content is the characteristic of Meghna sediments (FAO, 1971).

Mica was the predominant mineral while chlorite and kaolinite were also present in good amounts in all soils. Smectite was present in twenty out of twenty four soils. Small amounts of vermiculite and vermiculite-chlorite intergrade were also present in almost all soils. Moslehuddin et al. (1998) reported the mineralogy of two soils of AEZ 18 as mica, smectite and chlorite in good proportion with some amounts of kaolinite and vermiculite minerals, which was broadly similar to the results obtained in the present study. Moslehuddin et al. (1999) 
A) Ramgati-1

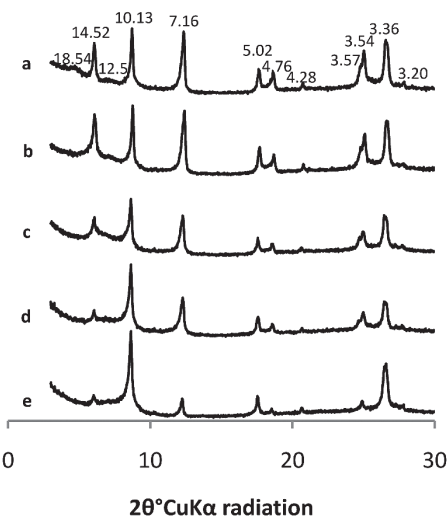

C) Hatiya-2

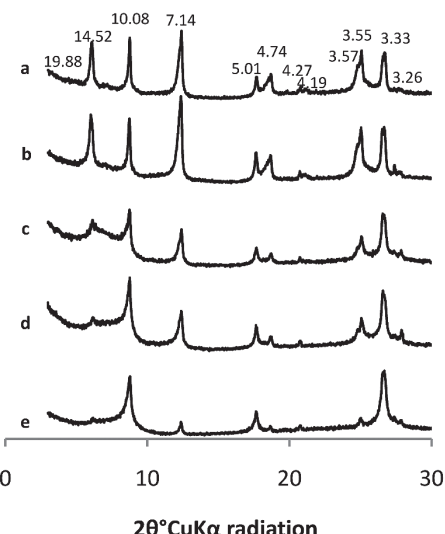

B) Ramgati-8

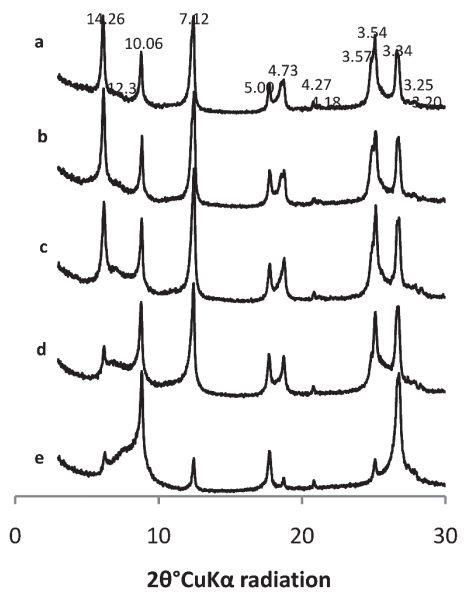

D) Silonia-3
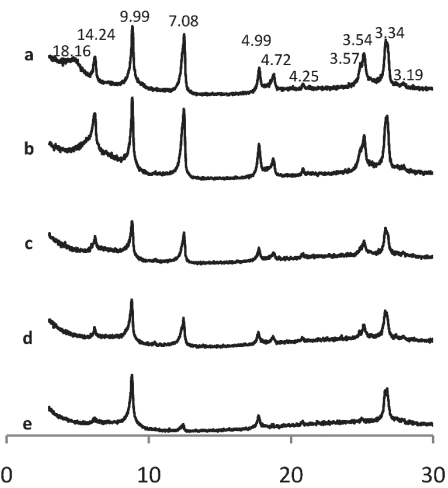

$2 \theta^{\circ} \mathrm{CuK} \alpha$ radiation

Fig. 1. X-ray diffraction patterns of the $<2 \mu \mathrm{m}$ clay fraction of A) Ramgati-1, B) Ramgati-8, C) Hatiya-2 and D) Silonia-3 soils. Spacing is in A. Treatments: a, Mg-saturation and glycerol-solvation; $\mathrm{b}, \mathrm{Mg}$-saturation and air-drying; c, K-saturation and air-drying; d, K-saturation and heating at $300^{\circ} \mathrm{C}$; e, K-saturation and heating at $550^{\circ} \mathrm{C}$

while preparing a tentative clay mineralogical map of Bangladesh put the soils of AEZ 18 in the mica-smectite suite, although almost no data was available on mineralogy of this AEZ. They supposed that the soils of Young Meghna Estuarine Floodplain were originated from the Ganges sediments mainly, with admixture of the Brahmaputra (Jamuna) and Meghna sediments, and assumed that these regions have mica-smectite suite. They also opined that due to decalcification of the Ganges sediments and/or admixture of the Brahmaputra and Meghna sediments, smectite may not always be a dominant mineral, and vermiculite and chlorite may be present in high proportions. The details mineralogy of the AEZ 18 presented in this paper is the first of its kind and the assumption made by Moslehuddin et al. (1999) was found to be partially true. Presence of high chlorite along with less dominance of smectite in some samples indicates that there is a contribution of Meghna/Old Brahmaputra sediments over the Ganges sediments in soils of AEZ 18 (Moslehuddin et al., 1999). However, twenty soils contained smectite, where the proportion of more than $10 \%$ was found in eight samples, which indicates dominance of the parent Ganges sediments in these soils. However, the study area was confined to a specific part of this AEZ and it is difficult to comment that what proportion of the soils have minor or fair amount of smectite.

Clay content and its mineralogical composition determine the inherent potentiality of the soils. The soils having good amount of smectite and vermiculite should have high buffering capacity and nutrient holding capacity indicating its high inherent potentiality. Most soils of this AEZ had medium to good amounts of clay, which contained considerable amounts of smectite, with some vermiculite and/or chlorite-vermiculite intergrade minerals. Thus, the inherent potentiality would be moderate to good depending on the amounts of those minerals.

\section{CONCLUSIONS}

The soils of the AEZ 18, Young Meghna Estuarine Floodplain were mostly medium textured. Most of the 
Table 3. Approximate mineralogical contents (\%) in clay fraction $(<2 \mu \mathrm{m})$ of the sampled soils

\begin{tabular}{|c|c|c|c|c|c|c|c|c|c|c|}
\hline \multirow{2}{*}{ Soil series } & \multicolumn{10}{|c|}{ Minerals } \\
\hline & $\mathrm{Mc}$ & $\mathrm{St}$ & $\mathrm{Vt}$ & $\mathrm{Ch}$ & $\mathrm{Kt}$ & $\mathrm{Vt}-\mathrm{Ch}$ & $\mathrm{Mc}-\mathrm{Ch}$ & $\mathrm{Qr}$ & Gt & $\mathrm{Fd}$ \\
\hline Ramgati-1 & 43 & 8 & 6 & 20 & 11 & - & - & 11 & - & 1 \\
\hline Ramgati-2 & 47 & 4 & 7 & 18 & 8 & - & 2 & 11 & - & 3 \\
\hline Ramgati-3 & 39 & 2 & 2 & 25 & 11 & - & 2 & 12 & 1 & 6 \\
\hline Ramgati-4 & 34 & - & - & 19 & 19 & 9 & - & 16 & - & 3 \\
\hline Ramgati-5 & 45 & 6 & 7 & 23 & 13 & - & - & 4 & 1 & 1 \\
\hline Ramgati-6 & 47 & 14 & - & 18 & 12 & - & - & 6 & - & 3 \\
\hline Ramgati-7 & 47 & 16 & 4 & 15 & 10 & - & - & 6 & - & 2 \\
\hline Ramgati-8 & 29 & - & - & 24 & 19 & 16 & - & 8 & 1 & 3 \\
\hline Ramgati-9 & 42 & 13 & 4 & 19 & 15 & - & - & 5 & - & 2 \\
\hline Ramgati-10 & 53 & 10 & - & 16 & 14 & - & - & 6 & - & 1 \\
\hline Ramgati-11 & 46 & 4 & 2 & 19 & 15 & - & - & 12 & - & 2 \\
\hline Ramgati-12 & 46 & 4 & - & 26 & 19 & - & - & 4 & - & 1 \\
\hline Ramgati-13 & 38 & 7 & 7 & 24 & 17 & & - & 5 & - & 2 \\
\hline Hatiya-1 & 49 & 5 & - & 20 & 12 & - & - & 11 & - & 3 \\
\hline Hatiya-2 & 37 & - & 8 & 26 & 15 & - & - & 9 & 2 & 3 \\
\hline Hatiya-3 & 52 & - & 6 & 16 & 4 & - & - & 11 & - & 11 \\
\hline Hatiya-4 & 45 & 7 & - & 19 & 10 & 3 & - & 13 & - & 3 \\
\hline Hatiya-5 & 53 & 7 & - & 20 & 12 & - & - & 6 & - & 2 \\
\hline Hatiya-6 & 52 & 10 & 3 & 14 & 11 & - & - & 8 & - & 1 \\
\hline Hatiya-7 & 48 & 11 & - & 17 & 12 & - & - & 9 & - & 3 \\
\hline Hatiya-8 & 48 & 5 & 6 & 18 & 13 & - & - & 8 & - & 2 \\
\hline Silonia-1 & 28 & 6 & 4 & 24 & 20 & 12 & - & 3 & 1 & 2 \\
\hline Silonia-2 & 50 & 11 & - & 17 & 11 & - & - & 8 & - & 1 \\
\hline Silonia-3 & 43 & 13 & - & 18 & 14 & - & - & 10 & - & 2 \\
\hline
\end{tabular}

Abbreviation: Mc, mica; St, smectite; Ch, chlorite; Vt, vermiculite; Kt, kaolinite; Qr, quartz; Fd, feldspar; Vt-Ch, vermiculite-chlorite intergrade; Mc-Ch, Interstratified mica-chlorite.

soils had good amounts of clay. The mica, chlorite and kaolinite were found most predominant minerals in all the soil samples along with some smectite, vermiculite and/or chlorite-vermiculite intergrade minerals in the clay fraction. Smectite was present as a dominant mineral in several samples. Therefore, the results of the present study partly support the mineralogical suite of mica-smectite for AEZ 18 as proposed by Moslehuddin et al. (1999). More study is required with soils from other locations of this AEZ. The findings of the research are useful for solving soil related problems and for consideration of land use and management, especially in terms of nutrient and water management and selection of crops and so on.

\section{ACKNOWLEDGEMENTS}

We are very grateful to Dr. Md. Mofizur Rahman Jahangir, Associate Professor, Department of Soil Science, Bangladesh Agricultural University, Mymensingh, and staffs of Soil Resource Development Institute (SRDI) for helping in collection of the soil samples for this study.

\section{REFERENCES}

AIS 2013 Krishi Diary (In Bengali). Agriculture Information Service, Ministry of Agriculture, Dhaka (Bangladesh) p. 2.

BARC 2012 Fertilizer Recommendation Guide. Bangladesh Agricultural Research Council, Farm-Gate, Dhaka (Bangladesh) p. 274

FAO 1971 Bangladesh: Soil Resources. AGL: SF/ PAK 6, Technical Report No. 3, Rome (ltaly), p. 211

FAO-UNDP 1988 Land Resources Appraisal of Bangladesh for Agricultural Development. Report 2. Agroecological Regions of Bangladesh. FAO, Rome (Italy) p. 570

Islam, M. N., A. Z. M. Moslehuddin, A. K. M. M. Hoque, I. U. Ahmed and K. Egashira 2003 Mineralogy of soils from different Agroecological Regions of Bangladesh: Region 1 - Old Himalayan Piedmont Plain. Clay Sci., 12: 131-137

Moslehuddin, A. Z. M., Saheed, S. M. and Egashira, K. 1998 Mineralogical approach to alternation of different river sediments in Meghna Floodplains soils of Bangladesh. Clay Sci. 10: $375-384$

Moslehuddin, A. Z. M. and K. Egashira 1996 Mineralogical composition of some important paddy soils of Bangladesh. Bull. Inst. Trop. Agr., Kyushu Univ., 19: 33-54

Moslehuddin, A. Z. M., M. S. Hussain, S. M. Saheed, and K. Egashira 1999 Clay mineral distribution in correspondence with agroecological regions of Bangladesh soils. Clay Sci., 11: 83-94 